some other points, are not recorded in a sufficient number of cases to admit of reliable averages being made.

The practice carried out in the foregoing series of cases was as follows. The operations were slowly performed. After separating the skin from the gland tissue, including the tumour, an incision was made around the superior half of circumference down to the fibres of the great pectoral muscle, and the mass torn, not dissected, off the muscle affected axillary glands were always removed. All bleeding points observed were tied, and ordinary silver sutures were used in bringing the edges of the wound together The arm of the side operated upon was thrown across the chest and fixed there, with the object of relaxing the skin and great pectoral, and keeping the wound as nearly as possible free from disturbance. This practice was followed unt the woman left the hospital. When any tendency to bronchitis existed the patient was placed sitting up in bed, or as nearly so as possible, immediately after the operation. So far as I can learn a fatal termination in mammary operations occurs either from pneumonia, pyæmia, or erysipelas, or from exhaustion. By operating under the spray and dressing antiseptically, pyæmia may be prevented; the dragging which tends to erysipelatous jnflammation may be in most cases avoided by fixing the arm in front of the chest, and pneumonia may be averted by keeping the patient as much as possible in the sitting posture trom the date of the operation, as well as by carefully avoiding draughts and seeing that the windows next to the woman's bed are kept closed during the prevalence of an east wind. The cases were all treated antiseptically, and only four or five required any stimulants. The most promising cases of scirrhus for removal-that is to say, those in which the longest interval of good health may elapse before the return of the disease-are those met with in spare women of advanced age, with a slow pulse, and in whom the tumour has grown slowly. The more rapidly the growth has taken place, the speedier will be the return after operation. Fat wheezv patients are, in my experience, the most unpromising subjects, and require the greatest care they are, in fact, amongst the worst class of patients for any surgical operation. No case of scirrhus existing in both mammæ at the same time has come under my observation. I am distinctly of opinion that scirrhus of the mamma is never a purely local disease.

Glasgow.

\section{BULLOUS ERUPTION OF A PECULIAR CHARACTER.}

BY RICHMOND LEIGH, M.R.C.S. ENG., SURGEON TO THE ST. GEORGE'S HOSPITAL FOR DISEASES OF THE SKIN, LIVERPOOL.

M. W—, aged thirty-three, very healthy, was affected by a peculiar eruption five days after parturition. It appeared as bullæ of irregular shape and size, varying from a quarter of an inch to about one inch in size. It was not preceded by redness, pain, or other sign or symptom. But for the absence of redness, the appearance was that of a blister, for which it was taken by a surgeon who saw the case early. As the bullie burst, there was some slight rawness from the loss of epithelium, but not beyond the margin of the bullæ, and al ro some slight soreness and purulent discharge from the friction of the clothes, but no pain existed from other cause throughout the course of the disease. The height of the eruption was reached about three or four days from its commencement, and fresh bullæ appeared at intervals in its course for over a week. After the discharye of the contained fluid the bullæ dried up gradually with little reddening, rawness, or discharge, except where irritated by rubbing. Accompanying the eruption was an eczematous affection of the eyes and lip;, which remained after the disappoarance of the former. The trunk was the only part affected, and with the exception of a portion of the buttocks, only on the anterior aspect, which was irregularly covered by the eruption from the neck to the groins. The duration of the complaint was about fourteen days. It was probably of neurotic orgin, the result of "cold," but no nerve region was specially marked out. There was no fever, and the general health was unaffected, except that there was some little debility more than usual. No history of syphilis was elicited, and the woman had had no abortions, or stillborn or premature children. She was married verz early, soon after the age of fourteen, and had had eleven children before the present one. The milk appeared on the third day, without much febrile disturbance.

The treatment was general ; iron and quinine on account of the debility, and vaseline locally.

Park-road, Liverpool.

\section{PENETRATING WOUND OF THE ORBIT;} BULLET LODGED IN THE BRAIN.

BY A. EMRYS-JONES, M.D.,

SURGEON TO THE ROYAL EYE HOSPITAL, MANCHESTER.

ON Monday, Nov. 6th, I was summoned in a great hurry to see a case in consultation with my friend Mr. W. Armstrong, of Harpurhey, who informed me that a boy, aged fourteen, a few hours previously had been handling a revolver, the contents of which had been discharged into the orbit, and most likely into the brain. The boy was evidently in pain, and it was deemed advisable to give him a few drops of chloroform before proceeding to make an examination ; but just as he took the first few sniffs he struggled violently, and then fell into a state of collapse, and, in spite of all that could he done, he did not breathe again, although the action of the heart kept up for some time.

On Nov, 8th we made a post-mortem examination, and found the following appearances:-The eyeball was extensively ruptured, and internally a large irregular opening, about half an inch in extent, at the junction of the ethmoid and sphenoid bones, and continuous with the opening a large hole extending through the cerebral convolutions to within an inch of the posterior boundary, where we found the bullet.

The track was filled with blood, and the débris of bone carried along with the bullet. There was extensive hæmorrhage into the adjacent parts and the ventricles. We found all the other organs healthy.

Manchester.

\section{ge attirror}

OF

\section{HOSPITAL PRACTICE, BRITISH AND FOREIGN.}

Nulla autem est alia pro certo noscendi via, nisi quamplurimas et morborum et dissectionum historias, tum aliornm tum proprias collectas habere, et inter se comparare.-Morgagni De Sed. et Caus. Morb., lib. iv. Procmium.

\section{ST. THOMAS'S HOSPITAL.}

LARGE AXILLARY ANEURISM; LIGATURE OF THE SUBCLAVIAN ALTERY; RECOVERT.

(Under the care of Sir WM. Mac CoRmac.)

For the following notes we are indebted to Dr. W. A. Duncan, house-surgeon.

The patient, a man aged forty-nine years, was admitted on Aug. 2lst, 1882. He had been healthy, and had followed the occupation of a carpenter. He was of very stout habit of body and florid complexion. Formerly, for six years he had been a soldier, and served during the Crimean campaign. At Scutari, in 1856 , he suffered from an attack of inflammation of the lungs, for which he was bled and cupped. In 1857 he had a chancre and bubo, and some weeks later his body was covered with a rash. He remained well till 1875, when he strained his right arm at his work, and lost the use of it for a time. The power was gradually regained, but a small lump about the size of a walnut was soon discovered in the rigbt axilla. Of this he took little notice, as it occasioned liim but trifling uneasiness. A month before admission he again strained the arm, and the tu mour now began to increase much more rapidly, especially during the week previous to admission; the skin over it became ecchymosed in places, and the man suffered some pain and numbness down the arm, which became considerably swollen.

When he first came under observation at the hospital 